\title{
BRI Offers Development and NOT Debt Trap
}

ISSN: 2637-7659

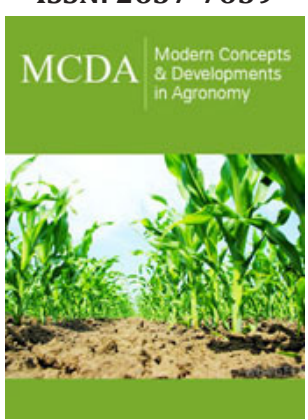

*Corresponding author: Ehizuelen Michael Mitchell Omoruyi, Center for Nigerian Studies at the Institute of African Studies, China

Submission: 㭗June 20, 2019

Published: 侮June 28, 2019

Volume 4 - Issue 4

How to cite this article: Mitchell O E. BRI Offers Development and NOT Debt Trap. Mod Concep Dev Agrono.4(4). MCDA.000594.2019.

DOI: 10.31031/MCDA.2019.04.000594

Copyright@ Mitchell Omoruyi EM, This article is distributed under the terms of the Creative Commons Attribution 4.0 International License, which permits unrestricted use and redistribution provided that the original author and source are credited.

\section{Ehizuelen Michael Mitchell Omoruyi}

Center for Nigerian Studies at the Institute of African Studies, Zhejiang Normal University China

\section{Opinion}

Millions of articles have been written on China and Africa engagement that involves the "Sino-optimism", "Sino-pragmatism", and "Sino-pessimism". With that said, somehow, based on these millions of articles China has been frequently trapped in metaphors about "traps" that form some Western media headlines such as "Can China circumvent the middle-income trap"? "China's trapped transition", "The Thucydides Trap" with the United States and the "Debt Trap". As for the last "trap" which is the debt trap, it refers to the idea that Chinese infrastructure loans in the continent of Africa are a strategy by the "Middle Kingdom" to extract concessions and purchase allegiance. I do not concur! China's involvement with African nations is far beyond building railways, bridges and roads. It is a bold experiment whether China's development model having produced prosperity in China, can be transplanted to the continent of Africa. The Chinese development model has already found favor in some East African nations, which have embraced aspects of the model through Chinese sizeable involvement in the region. The development model is typically composed of numerous major ingredients: strategies and subsidies that bolster exports as well as imitating technology and know-how, industrial park investment dynamic, investment in manufacturing, which could encourage positive spillovers and unlock economic potential in value-adding industries across the region via the complementary nature of trade-facilitating infrastructure and export-oriented industrial zones, and in turn go a long way toward eliminating poverty. With that said, these above ingredients are the epitome of catch-up growth that can clarify China's four decades of economic success, which the Chinese government is sharing with the world under the umbrella of Belt and Road initiative. Under the initiative, China seeks to promote a more linked world brought together by a web of Chinese-financed physical and digital infrastructure. In the past, Africa was at the mercy of the Western imperialist power coupled with their brutal monetary institutions. But that scenario is changing because the continent of Africa has suddenly found an alternative-China. African nations have been freeing themselves, realizing their various nations hidden potential; all this due to BRI. The BRI is not only about the economy, infrastructure and development, it is also about culture, health, knowledge and the well-being of the people. It is aiming at linking individuals at diverse races, life, philosophies, and beliefs. And the leaders in the West are bothered.

Nothing borders the West more than the prospect of losing absolute control over the globe. For the West, it is not (and at no time was it) about improving the well-being of hundreds of millions of poor persons. The West had centuries of total control over the world, and all they did was to enrich themselves by stealing from every corner of the globe, most especially in Africa. The West believes it is all about 'winning or losing' and maintaining its colonies and 'client' nations; by all means. For China, (via BRI) it is about shared prosperity. The strong belief in China was and will always be: building a better Africa and a better world; if the global economy is doing well and fruitful, China will flourish as well. China does not build its prosperity on plunder as the West has been doing for many decades. Western headlines might claim BRI is not perfect and speak of debt trap issue continually, but on the worldwide scale, BRI is the best the world has presently. And it has been making headway, week after week and month after month, making the initiative the exact opposite to the Western imperialism and colonialism. With that said, while most nations in East Africa have performed better than other nations in Sub-Saharan Africa as a result of the huge investment in infrastructure as a result of BRI, IMF 
has raised alarm about sharp rise of debt in Ethiopia and Djibouti. Arguably, BRI could radically lessen the costs of international trade as well as underpin the economic transformation of poor nations. A World Bank report asserts that if accompanied by efficiencybolstering policy reforms, transport cost could drop by a quarter in some BRI nations as a result of the fact that infrastructure has a significant multiplier effect. Due to the multiplier effect, largescale infrastructure programmes have been launched in all East African nations as an essential part of long-term development plans outlined by the government to inject economic vitality into the region's economy. Some of the long-term infrastructure development plans have started yielding profits. For instance, the BRI which is connected with the Chinese-built and financed Nairobi-Mombasa railway has ferried over 2.5 million passengers and almost 3.9 million tons of cargo since its launch in May 2017. Also, Kenya economy has improved by 1.5 percent, and the railway has created over 50, 000 employment for Kenyan inhabitants. As a result, Kenyan President Kenyatta plaudits this grand project and listed it among the top 13 most magnificent railway tours for 2019 In Ethiopia, a novel Chinese-built and financed terminal at its capital airport was inaugurated in January 2019 with an annual capacity to serve nearly 22 million passengers. It tripled the airport's capacity, contributing to Ethiopia's efforts to become a major aviation hub of the continent of Africa. With the implementation of the BRI in some East African nations, China is attempting to show these nations the way to prosperity, and this proves how much China respects the value of friendship with East African nations. As such, East African nations are snowballing their engagement with the
Chinese under the BRI not because it is changing their balance sheet in form of draining their finances which the West thinks can lead to a debt trap, but because of the economic benefits, it brings to them as a result of profitability and affordability. As a result, for the first time, East African governments have been able to turn the region's resources advantage into development advantage. Notably, China and participating nations have jointly adopted the Guiding Principles on funding the development of BRI projects, which highpoints the necessity to ensure debt sustainability. During the 2019 second Belt and Road Forum in Beijing, China published the Debt Sustainability Framework for participating nations of the BRI. With this publication, China is creating an avenue for mutual understanding with each pact, making the BRI turning out to be more transparent, self-regulating and improving with each pact. According to a report published in Belt and Road Advisory and cited from Financial Times on April 29, 2019 titled "BRA Fact Check: The BRI is NOT a Debt Trap", referred to Rhodium Group examination of 38 Chinese debt renegotiations with 24 nations in the past decade. The article asserts that China leverage remains limited, with most of the negotiations resolved in favour of the borrower. Debt cancellation were found in 14 cases, and deferments in 11 cases. As such, arguably, the BRI is definitely not a "debt trap" initiative that nations may fall into, but an "economic vitality" that can inject economic prosperity into all participating nations economy; like the Chinese Ambassador to Rwanda puts it: It is via participating in the BRI collaboration that numerous nations are getting out of the trap of "no development". 